УДК 330

DOI: https://doi.org/10.54929/pmtl-issue1-2021-12

\title{
РЕАЛІЗАЦІЯ МЕХАНІЗМУ ДЕРЖАВНО-ПРИВАТНОГО ПАРТНЕРСТВА В УКРАЇНІ: СУЧАСНІ РЕАЛІЇ ТА ПЕРСПЕКТИВИ
}

\author{
IMPLEMENTATION OF THE MECHANISM OF PUBLIC - PRIVATE \\ PARTNERSHIP IN UKRAINE: MODERN REALITIES AND PROSPECTS
}

\author{
Косач I. A. \\ доктор економічних наук, профресор, \\ професор кафедри публічного управління \\ та менеджменту організацій, \\ Національний університет «Чернігівська політехніка» \\ ORCID ID: 0000-0003-1730-7140
}

Кулик О. С. аспірантка кафедри публічного управління та менеджменту організацій, Національний університет «Чернігівська політехніка» ORCID: 0000-0001-5787-8787

\author{
Iryna Kosach \\ Doctor of Economics, Professor, \\ Professor of Department of Public Administration \\ and Organizations' Management, \\ Chernihiv Polytechnic National University
}

Oleksandra Kulik

Postgraduate student, Department of Public Administration and Organizations' Management,

Chernihiv Polytechnic National University

В статті розглянуто характерні риси механізмів взаємодії державного і приватного секторів, визначено принципові відмінності державно-приватного партнерства та приватизації. На основі відмінностей інтересів державного та приватного партнерів та можливості їхнього задоволення існуючими в Україні нормативно-правовими, фрінансовими та організаційними інструментами проаналізовано проблеми державно-приватного партнерства та обгрунтовано, що основними умовами успішної підготовки та реалізації різних форм державно-приватного партнерства, які сприяють підвищенню їх результативності, є інформаційна підтримка, розробка реальних проєктів, врахування думки івимог населення територій і працівників. Деталізовано основні принципи ефрективного управління державно-приватним партнерством. Виокремлено проблеми впровадження та реалізації механізму державно-приватного партнерства, визначено умови, за яких його використання $\epsilon$ есрективним в контексті реалізації державної політики соціально-економічного розвитку. Ключові слова: державно-приватне партнерство, механізм, партнерські відносини, публічне адміністрування, проєкт, приватизація.

В статье рассмотрены характерные черты механизмов взаимодействия государственного и частного секторов, определены принципиальные отличия государственно-частного партнерства и приватизации. На основе рассмотрения различий интересов государственного и частного партнеров и возможности их удовлетворения существующими в Украине нормативно-правовыми, фринансовыми и организационными инструментами проанализированы проблемы государственно-частного партнерства и обосновано, что основными условиями успешной подготовки и реализации различных фоорм государственно-частного партнерства, которые способствуют повышению их результативности, является инфрормационная поддержка, разработка реальных проектов, учета мнения и требований населения территорий и работников. Детализированы основные принципы эфффективного управления государственно-частным партнерством. Выделены проблемы внедрения и реализации механизма государственно-частного партнерства, определены условия, при которых его использование является эффективным в контексте реализации государственной политики социально-экономического развития. Ключевые слова: государственно-частное партнерство, механизм, партнерские отношения, проект, приватизация.

The purpose of the article is to study the elements of the mechanism of public-private partnership, the conditions that form the optimal environment for PPP projects in Ukraine, the range of fundamental problems associated with the 
effective implementation of PPP in the practice of state property management, and possible solutions. Serious infrastructural problems that have accumulated in Ukraine it is currently impossible to solve by the state alone. At the same time, full-scale privatization of state infrastructure assets is impossible and is not always an effective way to shift the development of these industries to the private sector. The answer to the current situation is the generally accepted world practice of public-private partnership (PPP), the advantage of which is the involvement in the traditional public sectors of the economy of private business practices, as well as the desire to eliminate the shortcomings of both methods of management through optimal allocation of resources. The article considers the characteristic features of the mechanisms of interaction between the public and private sectors, identifies the fundamental differences between public-private partnership and privatization. Based on the differences between the interests of public and private partners and the possibility of their satisfaction with the existing legal, financial and organizational instruments in Ukraine, the problems of public-private partnership are analyzed and it is substantiated that the main conditions for successful preparation and implementation of various forms of public-private partnership effectiveness, there is information support, development of real projects, taking into account the views and requirements of the population of the territories and workers. The basic principles of effective management of public-private partnership are detailed. The problems of implementation and realization of the mechanism of public-private partnership are singled out, the conditions under which its use is effective in the context of realization of the state policy of social and economic development are defined. Key words: public-private partnership, mechanism, partnership relations, project, privatization.

Постановка проблеми. Серйозні інфраструктурні проблеми, що накопичилися в Україні за десятиліття відсутності уваги до стану автомобільних доріг, залізничного та комунального господарства, морських і річкових портів, неможливо в даний час вирішити силами тільки держави. При цьому брак фрінансування - не єдина перешкода на шляху модернізації та розвитку: відсутність повноцінного бачення цілей, завдань і шляхів виходу галузей з кризового стану, високий ступінь бюрократизації прийняття рішень, невисока кваліфрікація в сфрері управління інфрраструктурними проєктами також негативно впливають на результативність державного управління. У той же час повномасштабна приватизація державних інфраструктурних активів неможлива і не завжди $\epsilon$ ефрективним способом перекласти завдання розвитку зазначених галузей на плечі приватного сектора. Відповіддю на ситуацію, що склалася, є загальноприйнята світова практика державно-приватного партнерства (ДПП), перевагою якого є залучення в традиційно державні сектора економіки практик ведення бізнесу.

Аналіз останніх досліджень і публікацій. Проблематика державно-приватного партнерства тривало і активно розглядається зарубіжними вченими, які напрацювали істотну методологічну базу, що знайшла відображення в рекомендаціях по державно-приватному партнерству таких організацій, як Світовий банк, Міжнародний і Азіатський банки реконструкції та розвитку, ЮНКТАД, Європейська комісія, ЕСКАТО, в національних посібниках з імплементації ДПП розвинених і країн, що розвиваються. Актуальній задачі застосування ДПП в Україні присвячені роботи таких вчених, як І. Запатріна, [5; 7], О. Винник [3], Н. Бондар [1; 2], К. Павлюк [8], А. Пильтяй [9] та інших дослідників і фахівців-практиків. Коло їх інтересів стосується методології та практики застосування механізму державно-приватного партнерства для цілей державного управління і рішення задач розвитку окремих галузей. Проблемними сферами, які вимагають максимальної уваги при реалізації проєктів ДПП, називають законодавчу базу, інституційне забезпечення, сфреру прийняття рішень, та дотримання прав приватного партнера, політичну і економічну нестабільність. При цьому недостатньо уваги приділяється питанням негативного сприйняття українським суспільством самого механізму державно-приватного партнерства та недовіри до учасників проєктів, його ототожнення з відкладенням приватизації і присвоєнням державної власності окремими приватними структурами.

Також виникає необхідність вивчення відмінностей між механізмами державно-приватного партнерства, приватизації та традиційними держзакупівлями для фрормування адекватного сприйняття першого в структурах державної влади, бізнес-середовищі і суспільстві.

Формулювання цілей статті (постановка завдання). Метою статті $є$ дослідження елементів механізму державно-приватного партнерства, умов, які формують оптимальне середовище для реалізації проєктів ДПП в Україні, кола основоположних проблем, супутніх ефрективній імплементації ДПП в практику управління, і можливих напрямків їх вирішення.

Виклад основного матеріалу дослідження. В Україні внаслідок сформованих стереотипів взаємовідносин держави і приватного бізнесу, а також відсутності ефективного їх правового регулювання поряд зі зменшенням значущості громадських інтересів державно-приватне партнерство більшістю його потенційних учасників і зацікавлених сторін розглядається як завуальований корупційний перерозподіл державної власності. Крім того, в публічних дискусіях представники державних підприємств (профрспілкові лідери, керівництво) найчастіше оцінюють розширення тренду державно-приватного партнерства у виробничій сфрері економіки як перехідний етап до приватизації найбільш привабливих дер- 
жавних активів, роблячи акцент на невигідність такої практики активного залучення приватного капіталу. Однак державні підприємства, що забезпечують істотний грошовий потік до бюджетів усіх рівнів - це швидше виняток з правил в сучасній українській економіці. Недоліком $є$ не тільки фінансування, а й нові виробничі й управлінські технології, які роблять неможливим активне зростання підприємств держсектора. Саме цей факт береться до уваги при популяризації різних форм державно-приватного партнерства в Україні.

Вивчивши думки вчених-економістів і фрахівців міжнародних інститутів, що займаються питаннями імплементації державно-приватного партнерства, можна зробити висновок про сутність досліджуваних відносин.

Отже, державно-приватне партнерство в Україні - система відносин між державним та приватним партнерами, при реалізації яких ресурси обох партнерів об'єднуються з відповідним розподілом ризиків, відповідальності та винагород (відшкодувань) між ними, для взаємовигідної співпраці на довгостроковій основі у створенні (відновленні) нових та/або модернізації (реконструкції) існуючих об'єктів, які потребують залучення інвестицій, та у користуванні (експлуатації) такими об'єктами[4]. В той самий час під приватизацією в цілому розуміється передача державного активу в приватний сектор на необмежений термін шляхом його продажу. При цьому принциповими відмінностями державно-приватного партнерства від приватизації $\epsilon$ :

- по-перше, ризики, пов'язані з діяльністю, при приватизації повністю лягають на приватний сектор, тоді як при державно-приватному партнерстві їх розподіл обумовлюється в договорі;

- по-друге, після приватизації участь державних органів влади в діяльність підприємства обмежується регулюючим впливом, тоді як при державно-приватному партнерстві держсектор частково несе відповідальність за результат роботи підприємства, якість послуг, що надаються.

Аналіз механізмів традиційних закупівель в держсекторі, державно-приватного партнерства і приватизації також дозволив виявити основні відмінності в даних підходах, основним з яких $є$ розподіл відповідальності та вигоди від реалізованих проєктів (Табл. 1).

Таким чином, в якій би формі не існувало державно-приватне партнерство, при сумлінній його імплементації ставити знак рівності між ним і приватизацією неправильно. У той же час, якщо основна роль приватного партнера в проєктах державно-приватного партнерства пов'язана 3 досягненням певного рівня ефективності, якості послуг, що надаються, фрінансового та інновацій- ного забезпечення, роль і функції державного партнера набагато ширше, оскільки охоплюють сферу формування політики ДПП і оптимальних економічних, правових і соціальних умов для iï реалізації, розробки проєктів, забезпечення зрозумілої і прозорої схеми відбору приватного інвестора, оцінки ефективності їх пропозицій, визначення ризиків, створення системи моніторингу реалізації проєкту. Сумлінне опрацювання кожної зі сфрер відповідальності дозволяє не тільки підвищити економічну ефективність проєктів ДПП, але і забезпечити суспільне визнання даного механізму роботи з приватним сектором, дискредитоване роками корупції та зневажання державними інтересами.

У руслі вищесказаного найважливішими принципами участі держави в проєктах державно-приватного партнерства за допомогою різних органів виконавчої і законодавчої влади повинні стати такі основоположні установки [10]:

- участь і зацікавленість, тобто активна залученість в процедури розробки, реалізації, контролю проєктів;

- дотримання інтересів сторін, в тому числі майбутніх користувачів проєкту, а також населення, яке мешкає поблизу або на території реалізації проєкту;

- прозорість проєкту державно-приватного партнерства - відкритість процесів прийняття рішень, особливо що стосуються проведення конкурсів і тендерів, фінансування, захисту довкілля і безпеки для людини;

- підзвітність і відповідальність за прийняті рішення - державні органи влади повинні приймати обов'язок по відповідальності перед суспільством за якість, вартість, результативність реалізованих проєктів та їх безпеку;

- справедливість і дотримання правил при розподілі відповідальності, обов'язків і прав між учасниками проєкту, його користувачами, залучення населення, вирішення спорів відповідно до законодавства, наявність гарантій відшкодування ризиків;

- стійкість взаємодії і координація зусиль, відсутність конкуренції між державними органами і приватними інвесторами, а також всередині проєкту між його виконавцями.

Відповідно до зазначених принципів, сторонами розробляється така система управління відносинами державно-приватного партнерства, яка $€$ інструментом запобігання розвитку системних недоліків взаємодії, а також контролю його реалізації (табл. 2).

Однак поряд з реальними перевагами використання механізму державно-приватного партнерства (зниження державних витрат і економія ресурсів, поділ відповідальності і ризиків 3 приватним сектором, доступ до технологічних і 


\section{Характерні риси механізмів взаємодії державного і приватного секторів при реалізації проєктів}

\begin{tabular}{|c|c|c|}
\hline Традиційні держзакупівлі & Державно-приватне партнерство & Приватизація \\
\hline \multicolumn{3}{|c|}{ Загальний механізм взаємодії } \\
\hline $\begin{array}{c}\text { Держава в особі уряду формує } \\
\text { інфраструктурні активи підпри- } \\
\text { ємств }\end{array}$ & $\begin{array}{c}\text { Держава закуповує послуги підпри- } \\
\text { ємств, що працюють на принципах } \\
\text { державно-приватного партнерства } \\
\text { та фрормують активи за рахунок } \\
\text { різних джерел }\end{array}$ & $\begin{array}{c}\text { Держава в особі уряду } \\
\text { та інших органів влади закуповує } \\
\text { послуги у приватного сектора на } \\
\text { конкурентних умовах }\end{array}$ \\
\hline \multicolumn{3}{|c|}{ Договірна робота } \\
\hline $\begin{array}{c}\text { На процедури по фрормуванню } \\
\text { або закупівлі активів офрормля- } \\
\text { ється } \\
\text { короткостроковий договір }\end{array}$ & $\begin{array}{c}\text { Укладається договір ДПП, що вклю- } \\
\text { чає розробку, будівництво, фінансу- } \\
\text { вання, експлуатацію }\end{array}$ & $\begin{array}{l}\text { Укладається договір на закупівлю } \\
\text { послуг з приватним партнером }\end{array}$ \\
\hline \multicolumn{3}{|c|}{ Пріоритети проєкту } \\
\hline $\begin{array}{l}\text { Важливі вхідні характеристики } \\
\text { проєкту }\end{array}$ & Важливий результат проєкту & $\begin{array}{l}\text { Важливо отримати послугу за міні- } \\
\text { мальною вартістю }\end{array}$ \\
\hline \multicolumn{3}{|c|}{ Розподіл ризиків } \\
\hline $\begin{array}{l}\text { На держсектор лягає вся відпові- } \\
\text { дальність за ризики }\end{array}$ & $\begin{array}{l}\text { Частина ризиків проєкту приймає на } \\
\text { себе приватний сектор }\end{array}$ & $\begin{array}{c}\text { Всі ризики лежать на приватному } \\
\text { секторі }\end{array}$ \\
\hline \multicolumn{3}{|c|}{ Участь у фоінансуванні } \\
\hline $\begin{array}{c}\text { Капітальні витрати за проєктом і } \\
\text { поточні витрати лежать на } \\
\text { держсекторі } \\
\end{array}$ & $\begin{array}{c}\text { При закупівлі послуг у приватного } \\
\text { сектора } \\
\text { оплата настає за фрактом їх надання }\end{array}$ & $\begin{array}{l}\text { Фінансове забезпечення проєкту } \\
\text { лягає на приватного інвестора }\end{array}$ \\
\hline \multicolumn{3}{|c|}{ Розподіл відповідальності } \\
\hline $\begin{array}{c}\text { Відповідальність за якість, } \\
\text { вартість і терміни розробки } \\
\text { проєкту несе держсектор }\end{array}$ & $\begin{array}{c}\text { Інвестор несе відповідальність за } \\
\text { терміни будівництва і бюджет. Уряд - } \\
\text { за адміністративні процедури }\end{array}$ & $\begin{array}{c}\text { Відповідальність за будівництво } \\
\text { об'єкта, його вартість, якість } \\
\text { послуг лежить на приватному } \\
\text { секторі }\end{array}$ \\
\hline \multicolumn{3}{|c|}{ Суб'єкт експлуатації об'єкта } \\
\hline $\begin{array}{l}\text { Уряд експлуатує } \\
\text { об'єкт }\end{array}$ & $\begin{array}{c}\text { Залежно від договору експлуатує } \\
\text { об'єкт приватний партнер або дер- } \\
\text { жавний } \\
\end{array}$ & $\begin{array}{c}\text { Експлуатує об'єкт приватний } \\
\text { сектор, держава - купує } \\
\text { послуги } \\
\end{array}$ \\
\hline \multicolumn{3}{|c|}{ Критерії ефективності та результативності } \\
\hline $\begin{array}{c}\text { М'який підхід до проєкту по } \\
\text { критеріям якості, вартості, } \\
\text { термінам } \\
\end{array}$ & \multicolumn{2}{|c|}{$\begin{array}{c}\text { Стандарти якості, правила експлуатації об'єкта, термін його передачі в } \\
\text { держсекторі фріксовані та строго дотримуються }\end{array}$} \\
\hline
\end{tabular}

Джерело: складено автором на основі [9]

управлінських інновацій, розвиток окремих підприємств і секторів економіки, територій і регіонів) експерти в сфері взаємодії держави з приватним бізнесом виділяють певні проблеми, що ставлять під загрозу його ефективність, серед яких доцільно назвати наступні:

- недоліки забезпечення потенційних інвесторів необхідною інформацією про заплановані проєкти ДПП (коли уряд розробляє проєкти для залучення заздалегідь відомого інвестора);

- відсутність достатнього досвіду в приватному секторі, потенціалу і навичок в державному;

- неготовність державної інфрраструктури прийняття рішень до реалізації проєктів;

- більш висока вартість фрінансування в приватному секторі (призводить до зростання загальних витрат по проєкту);

- неможливість оптимального розподілу ризиків між учасниками.

При цьому аналіз досвіду використання дер- жавно-приватного партнерства в Україні дозволяє додати проблемні сфери, властиві саме вітчизняній практиці взаємодії держави і бізнесу, обумовлені невисоким рівнем ефективності роботи державних структур, а саме:

1) усвідомлення ролі, необхідності і можливості застосування різноманітних фрорм державно-приватного партнерства в різних галузях економіки, а також розподіл функцій між учасниками процесу;

2) законодавче забезпечення реалізації проєктів ДПП;

3) захист інтересів держави, інвестора і суспільства;

4) формування управлінського і кадрового базису для ефективного здійснення

проєкту на кожному етапі;

5) суспільне сприйняття необхідності передачі частини майна і функцій в приватний сектор в традиційно державних секторах економіки; 


\section{Деталізація основних принципів ефективного управління державно-приватним партнерством}

\begin{tabular}{|c|c|}
\hline Компоненти політики ДПП & Дії і процедури по ефективному управлінню ДПП \\
\hline \multicolumn{2}{|c|}{ Дотримання інтересів сторін і справедливість } \\
\hline $\begin{array}{l}\text { Проєктна документація і } \\
\text { система планів }\end{array}$ & $\begin{array}{c}\text { Позначення експертів, відповідальних за розробку проєктно-кошторисної } \\
\text { документації. Проєктування і розгорнуте планування. Адміністрування проєк- } \\
\text { тування, планування та ін. } \\
\text { Розробка контрактної документації. }\end{array}$ \\
\hline Контрактна документація & $\begin{array}{c}\text { Існуючі політико-правові особливості та нормативно-правові акти, правила і } \\
\text { стандарти ДПП. }\end{array}$ \\
\hline Вибір приватного партнера & $\begin{array}{c}\text { Процедура відбору приватного партнера. } \\
\text { Методика оцінювання конкурсних пропозицій. } \\
\text { Критерії оцінювання. }\end{array}$ \\
\hline \multicolumn{2}{|r|}{ Прозорість } \\
\hline Інформаційний менеджмент & $\begin{array}{l}\text { Система управління інфоомацією. } \\
\text { Класифікація інформації. } \\
\text { Засоби комунікації. }\end{array}$ \\
\hline Фінансовий менеджмент & $\begin{array}{c}\text { Фінансова та інвестиційна стратегія. } \\
\text { Програма стимулів і компенсацій. } \\
\text { Процедури і механізм розрахунків з приватним партнером. }\end{array}$ \\
\hline \multicolumn{2}{|r|}{ Підзвітність, участь і зацікавленість } \\
\hline $\begin{array}{l}\text { Участь користувачів і } \\
\text { громадськості }\end{array}$ & $\begin{array}{c}\text { Участь громадськості в плануванні і реалізації проєкту. } \\
\text { Аналіз потреби в проєкті. } \\
\text { Аналіз економічних і соціальних наслідків проєкту. }\end{array}$ \\
\hline Гарантія якості & $\begin{array}{c}\text { Будівельний нагляд. } \\
\text { Відбір субпідрядників. } \\
\text { Оцінка відповідності проєктним параметрам. }\end{array}$ \\
\hline Участь в управлінні & $\begin{array}{l}\text { Система навчання управлінню проєктами. } \\
\text { Наявність досвіду участі в проєктах ДПП. }\end{array}$ \\
\hline \multicolumn{2}{|r|}{ Ефрективність і результативність } \\
\hline $\begin{array}{l}\text { Система моніторингу і контр- } \\
\text { олю проєкту }\end{array}$ & $\begin{array}{c}\text { Система і структура доповідей про хід реалізації проєкту. } \\
\text { Процедури розгляду звітів по проєкту. }\end{array}$ \\
\hline Адміністрування проєк & цедура документування за проєктом і система звітної документації. \\
\hline
\end{tabular}

Джерело: складено автором на основі [6, с. 82]

6) відсутність чесної конкуренції між інвесторами та надання вільного

доступу на ринок проєктів ДПП.

Якщо деякі із зазначених проблем широко обговорюються вченими і фрахівцями (аналіз законодавства з ДПП і фрормування правової бази інвестицій, методика проведення конкурсів, створення структури, яка займається ДПП в Україна), то інші вимагають більш детальної опрацювання.

Практика і методологія державно-приватного партнерства, напрацьовані за десятиліття в країнах з різним рівнем розвитку економіки показали, що даний механізм не завжди є придатним для вирішення проблем конкретного підприємства, галузі, регіону.

Активне залучення приватного сектора ефрективний, проте не універсальний прийом забезпечення сталого розвитку. Він є доцільним, якщо:

- планується до реалізації великий проєкт, який вимагає оптимального управління ризиками, залучення значного обсягу фрінансування, проведення масштабного капітального будів- ництва;

- планується до реалізації серія схожих по суті і структурі проєктів, для чого можна розробити універсальну схему співпраці держави та інвесторів;

- в приватному секторі зосереджені досвід і знання, необхідні для реалізації проєктів;

- є підстави припускати, що вартість реалізації проєкту буде істотно нижче, а терміни - коротше за рахунок залучення приватного інвестора;

- представляється можливим чітко розподілити ризики між учасниками проєкту;

- тривалість проєкту і його вартість, характер використовуваних технологій, що беруть участь активів і послуг дозволять забезпечити відшкодування витрат інвесторів на протязі його життєвого циклу.

В інших випадках раціонально використовувати традиційну систему управління в державному секторі або використовувати більш радикальний спосіб зростання ефрективності - приватизацію.

Висновки 3 цього дослідження. Таким чином, основними умовами успішної підготовки та реалізації різних форм державно-приватно- 
го партнерства, які сприяють підвищенню їх результативності, ефрективності і сприйняття суспільством, є наступні:

1) розробка реальних проєктів, які вирішують актуальні завдання і задовольняють базові потреби в розвитку для конкретної галузі, підприємства, регіону, території, спільноти;

2) врахування думки і вимог населення територій і працівників підприємств через механізм громадських слухань соціально значущих проєктів, які зачіпають інтереси суспільства, колективного обговорення проєктів розвитку підприємства з поясненнями переваг і результатів їх реалізації, погроз і вигід для співробітників;

3) інформаційна підтримка в засобах масової інфрормації суспільно значущих проєктів для зниження соціальної напруженості і зростання рівня їх схвалення, що дозволить подолати опір негативних наслідків реалізації проєктів;

4) створення ефективних органів цивільного контролю реалізації великих проєктів, які зачі- пають інтереси місцевих органів влади, жителів територій, працівників підприємств;

5) створення кадрової основи успішної реалізації проєктів державно-приватного партнерства за рахунок: стажувань спеціалістів по ДПП в міжнародних організаціях, що займаються даною проблематикою, відповідних інститутах при урядах країн, активно і результативно використовують механізм ДПП; запрошення іноземних фрахівців, які в процесі роботи в команді з управління проєктом зможуть передати власний досвід на практиці; взаємодії з вищими навчальними закладами та спеціалізованими навчальними центрами, які готують фрахівців у сфрері управління проєктами.

Реалізація зазначених умов буде ефективною на основі якісного методичного забезпечення процедур управління проєктами шляхом фоормування загальнодоступної національної бази проєктів.

\section{БІБЛІОГРАФІЧНИЙ СПИСОК:}

1. Бондар Н.М. Концептуальні засади оцінювання суспільної ефеективності проєктів державно-приватного партнерства на транспорті. Управління проєктами, системний аналіз і логістика. Вип. 13. К.: НТУ. 2013. С. 25-32.

2. Бондар Н.М. Організаційно-економічний механізм партнерських взаємодій держави і приватного бізнесу у транспортній галузі. Управління проєктами, системний аналіз і логістика. Вип. 9. К.: НТУ, 2012. С. 260-263.

3. Вінник О.М. Технології державно-приватного партнерства (правові аспекти). Демографрія та соціальна економіка. 2012. № 1(17). С. 110-119.

4. Державно-приватне партнерство в Україні. 2021. URL: https:/luk.wikipedia.org/wiki. (дата звернення: 13.09.2021).

5. Запатріна І.В. Публічно-приватне партнерство в Україні: перспективи застосування для реалізації інфраструктурних проєктів і надання публічних послуг. Економіка і прогнозування. 2010. № 4. С. 62-86.

6. Круглов В. В. Механізми державного регулювання розвитку державно-приватного партнерства в Україні. URL: https://kbuapa.kh.ua/wp-content/themes/kbuapa/filesforpages/science/kvv_dis_20202606.pdf.(дата звернення: 13.09.2021).

7. Лебеда Т. Державно-приватне партнерство як фрактор економічного зростання та проблеми його розвитку в Україні. Економіст. 2011. № 3. С. 52-58.

8. Павлюк К.В. Сутність і роль державно-приватного партнерства в соціально-економічному розвитку держави. Наукові праці КНТУ. Економічні науки. 2010. Вип. 17. URL: http:// www.kntu.kr.ua/ doc/zb_17_ekon/ stat_17/02.pdf. (дата звернення: 13.09.2021).

9. Пильтяй O.B. Сучасні концепції та підходи до визначення державно-приватного партнерства. URL: http:// pd.onu.edu.ua/article/view/149577 (дата звернення: 13.09.2021).

10. Помогайло Б. В. Вектори удосконалення механізму реалізації державно-приватного партнерства у контексті забезпечення сталого розвитку. URL: http://www.dy.nayka.com.ua/?op=1\&z=1025. (дата звернення: 13.09.2021).

\section{REFERENCES:}

1. Bondar, N.M. (2013). Kontseptual'ni zasadi otsinyuvannya suspil'noï efektivnosti proektiv derzhavno-privatnogo partnerstva na transporti [Conceptual bases for evaluating the public effectiveness of public-private partnership projects in transport]. Project Management, Systems Analysis and Logistics. Vol. 13. Pp. 25-32. (in Ukrainian).

2.Bondar, N.M. (2012). Organizatsiino-ekonomichnii mekhanizm partners'kikh vzaєmodii derzhavi i privatnogo biznesu u transportnii galuzi. [Organizational and economic mechanism of partner interactions of the state and private business in the transport industry]. Project Management, Systems Analysis and Logistics. Vol. 9. Pp. 260263. (in Ukrainian).

3. Vinnyk, O.M. (2012). Tekhnologiï derzhavno-privatnogo partnerstva (pravovi aspekti). [Technologies of publicprivate partnership (legal aspects)]. Demography and social economy. № 1 (17). P. 110-119. (in Ukrainian).

4. Derzhavno-privatne partnerstvo v Ukraini. [Public-private partnership in Ukraine] (2021). URL: https:// uk.wikipedia.org/wiki. (accessed 13 September 2021). (in Ukrainian).

5. Zapatrina, I.V. (2010). Publichno-privatne partnerstvo v Ukraïni: perspektivi zastosuvannya dlya realizatsiï 
infrastrukturnikh proektiv i nadannya publichnikh poslug. [Public-private partnership in Ukraine: prospects for the implementation of infrastructure projects and the provision of public services]. Economics and Forecasting. № 4. Pp. 62-86. (in Ukrainian).

6. Kruglov, V.V. (2020). Mekhanizmi derzhavnogo regulyuvannya rozvitku derzhavno-privatnogo partnerstva $v$ Ukraïni. [Mechanisms of state regulation of public-private partnership in Ukraine]. URL: https://kbuapa.kh.ua/wpcontent/themes/kbuapa/filesforpages/science/kvv_dis_20202606.pdf. (accessed 13 September 2021). (in Ukrainian).

7. Lebeda, T. (2011). Derzhavno-privatne partnerstvo yak faktor ekonomichnogo zrostannya ta problemi iogo rozvitku v Ukraïni. [Public-private partnership as a factor of economic growth and problems of its development in Ukraine]. Economist. № 3. 52-58. (in Ukrainian).

8. Pavlyuk, K.V. (2010). Sutnist' i rol' derzhavno-privatnogo partnerstva v sotsial'no-ekonomichnomu rozvitku derzhavi. [The essence and role of public-private partnership in the socio-economic development of the state]. Scientific works of KNTU. Economic sciences. Vol. 17. URL: http: // www.kntu.kr.ua/ doc / zb_17_ekon / stat_17 / 02.pdf. (accessed 13 September 2021). (in Ukrainian).

9. Piltyay, O.V. Suchasni kontseptsiï ta pidkhodi do viznachennya derzhavno-privatnogo partnerstva. [Modern concepts and approaches to the definition of public-private partnership]. URL: http://pd.onu.edu.ua/article/view/149577 (accessed 13 September 2021). (in Ukrainian).

10. Pomogaylo, B.V. (2019). Vektori udoskonalennya mekhanizmu realizatsiï derzhavno-privatnogo partnerstva u konteksti zabezpechennya stalogo rozvitku. [Vectors for improving the mechanism of implementation of publicprivate partnership in the context of sustainable development]. URL: http://www.dy.nayka.com.ua/?op=1\&z=1025. (accessed 13 September 2021). (in Ukrainian). 